\title{
Horizontal Spatial Transformation of Home-Based Enterprises in Kampung Karangasem, Depok, Sleman
}

\author{
Luluk Rani Puspita1 and Dwita Hadi Rahmi² \\ ${ }^{1}$ Student of the Master of Architecture Program, Gadjah Mada University \\ ${ }^{2}$ Lecturer of the Master of Architecture Program, Gadjah Mada University
}

\author{
Article History \\ Received : 28 February 2019 \\ Accepted : 18 March 2019 \\ Published : 01 April 2019
}

\begin{abstract}
The number of student facilities around campus is proportioned to the number of students from out of town. The emergence of student facilities accommodated by the kampong (villages) around the university can be observed in Kampung Karangasem, Depok, Sleman. This phenomenon led to the concept of Home-Based Enterprises (HBE), which refers to residences transformed into business places. One of the ways to transform a house into HBE is by maximizing the space or land area horizontally without increasing the number of floors. In regard to that, this research aimed to study the horizontal spatial transformation in HBE in Kampung Karangasem. This study used the qualitative deductive approach with case study method. The findings reveal that the transformation of horizontal space involves the extending of space, sharing of space, shifting of space, and squishing of space.
\end{abstract}

Keyword: Spatial Transformation, Horizontal Transformation, Home-based enterprises

\section{Background}

Yogyakarta is famous for being a student city. This nickname is based on the rapid development of educational facilities in this city, especially at the college level. According to the Yogyakarta Provincial Government's Special Education and Sports Services, there are currently around 106 universities in the province of Yogyakarta Special Region. The number of universities is directly proportional to the number of students, especially students from outside the region, which makes up about $75 \%$ of the total number of students (www.detik.com, accessed on 17/04/2018). Subsequently, it results in the emergence of various facilities for students accommodated by the villages around campus; one of which is Kampung Karangasem, Depok, Sleman.

This opportunity allows the residents to

Correspondence: Luluk Rani Puspita

Student of the Master of Architecture Program, Gadjah Mada University

E-mail: Iuluk.rani.puspita@gmail.com utilize their residential areas to open various businesses, such as boarding houses, food stalls, laundry services, "warmindo" (instant noodle food stalls), photocopy services, and grocery stalls. This phenomenon gave rise to the concept of Home-Based Enterprises (HBE), i.e. residences that also serve as places of business. In HBE, changes are made in residential spaces to accommodate business in order to add value to land benefits and provide additional revenue for the res idents. The addition or change of space in a residential house as a space for economic activities can occur spontaneously or planned. In regard to that, this research is important as it aims to examine the horizontal spatial transformation in $\mathrm{HBE}$ in Kampung Karangasem.

\section{Literature Study}

Transformation is the process of changing architectural forms gradually into new forms which are responses to external and internal factors both physical and non-physical by considering the aspects of space and time. 
Horizontal Spatial Transformation of Home-Based Enterprises in Kampung Karangasem, Depok, Sleman Luluk Rani Puspita, Dwita Hadi Rahmi
This research focuses on spatial transformation, namely all matters relating to space or place (KBBI, 2017). Space is defined as a threedimensional geometry and a perceptual plane (Schulz, 1980). There are three things that are used as an indication of a change in the physical settlement of the land with elements that form a space, three of which include addition, elimination, and movement (Habraken, et al. 1983). According to Marti (1981) the application of spatial systems in relation to man, space and time can be classified into two factors, i.e. spatial structure (organization, hierarchy, circulation and spatial territory) and spatial values (meaning, function and use of space).

Spatial transformation in residential area refers to the "alteration" or "extension" which involves construction activities and uses materials and technology in the region (Tipple, 1991). Changes in a residential home can be done by changing the house vertically or horizontally (Yahya et.al, 2001 in Avogo et.al, 2017).

The scope of research is limited only to houses that function as HBE. HBE is an economic activity that is identical to the informal sector found in developing countries (Tipple, 2005). According to Strassman (1986) HBE is defined as a house that functions as a residence as well as a revenue generator. HBE is a smallscale business run by the family (Strassman, 1987). According to Gough et. al. (2001) HBE operations can be carried out by family members with or without employees. At a glance, 200 adds that HBE is not bound by certain rules whereby working capital, working hours, and work space can be regulated by the family.

From the various definitions of HBE above, it can be concluded that HBE is a residence as well as a revenue generator in the form of small-scale business run by families with or without employees by managing their own capital, hours, and work space.

HBE has three components consisting of business, family, and house. These three components will influence each other in HBE operational activities. The type of family will determine the type of business. The type of business will determine the space requirements, and the use of business space will affect the use of space in the house.
Figure 1. Components of HBE (Source: Marsoyo, 2012)

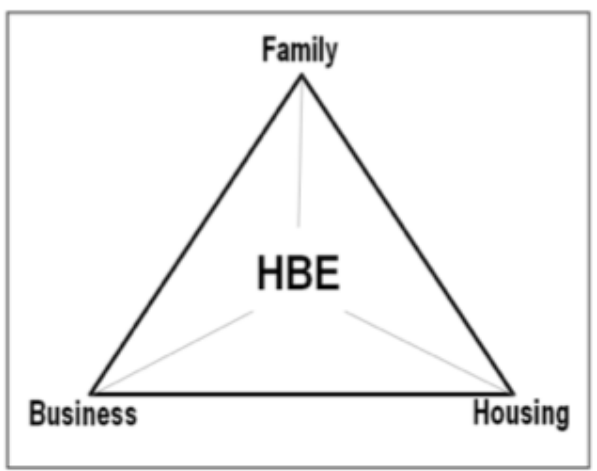

In the process of spatial transformation of residential houses into HBE, there are various strategies used by homeowners to create a business space. The transformation process can be achieved through: (1) reshaping an object, (2) changing patterns, (3) visual shifting by changing the physical aspects and the value of forms, and (4) adaptation and direct interaction with various forms of culture (Baper et.al, 2010). According to Marsoyo, the 2012 household adaptation strategies to "build spatial capital" in the HBE case consist of three categories: (a) Sharing of Space (b) Extending of Space and (c) Shifting of Space.

Research on the transformation of dwellings into HBE has been carried out by many researchers with different focuses and locations. The studies by Purwanto et.al. (2003) and Sumarjo (1999) were similar in the characteristics of the research location in the campus area. Purwanto et.al. (2003) and Sumarjo (1999) chose a case study on a specific HBE boarding house business. Purwanto et. al. (2003) used synchronic and diachronic phenomenological methods to see changes in houses (form and spatial) based on "kinship" which resulted in findings that change can reveal the dichotomous development between individual (commercial) interests \& efforts to maintain life order communal (kinship ties). This research differs from the author's research because the focus is not limited to boarding businesses, and diachronic methods are used to obtain the transformation process based on spatial adaptation.

Hartiningsih's research (2008) also have similarities with the current research, as it focuses on the spatial transformation near campus, as well as HBE types that vary and are not limited to boarding house only. The only difference is in the research method, in which 
the previous research uses a phenomenological method, while the current research employs a case study method. Moreover, Hartiningsih's research (2008) lays emphasis on the analysis of transformations based on synchronous conditions to analyze spatial forming elements, while this study uses a deronical approach to find adaptation strategies for spatial changes in each stage of transformation.

The description above shows that the author's research has some similarities and partial differences with previous studies. Prior to this study, the research subjects had never been discussed in one complete study, thereby producing new research findings that enrich the findings of previous studies.

\section{Location}

This research was conducted in Kampung Karangasem, Depok, Sleman. This Kampung is located in a suburb in the city of Yogyakarta. Kampung Karangasem belongs in the area of RW 02 (a community unit), which consists of 5 RTs or neigborhood units, namely RT 04, RT 05, RT 06, RT 07, RT 08.

Kampung Karangasem is now experiencing a development from traditional villages to urban villages. There were several phenomena of the period of $1959-2018$ which influenced the developmentprocess ofKampung Karangasem. Kampung Karangasem was originally a traditional village in which the land was typically used for dwellings, gardens (cassava and

Figure 2. Location of Kampung Karangasem (Source: Author's Analysis, 2018)

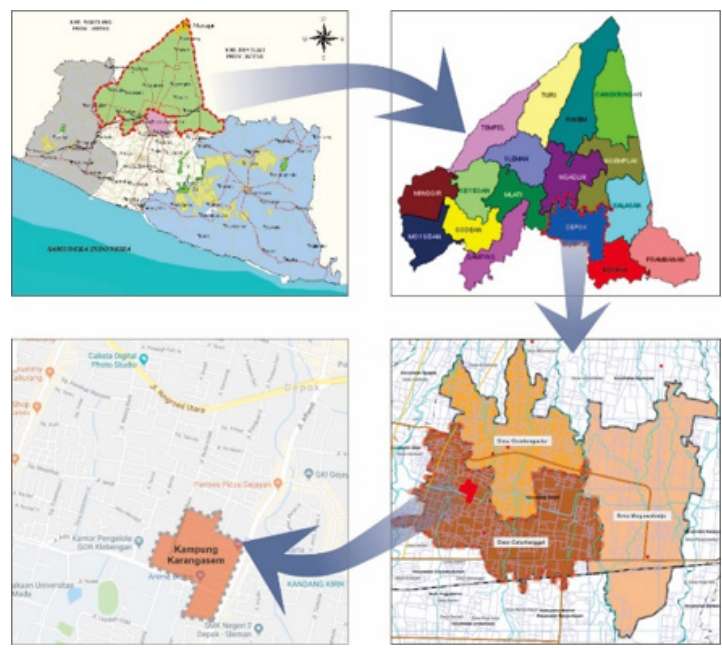

greens), or rice fields. At present, this village has been transformed into a very busy City Village.

\section{Research Methodology}

This research focused on the observation of spatial transformation horizontally in homes in Kampung Karangasem, Santren, Caturtunggal, Depok, Sleman, D.I.Yogyakarta which are used for economic activities as a result of the emergence of various educational facilities.

This study used the qualitative deductive approach. Deductive approach is a theoretical study of reasoning, contemplation, and experience to measure concepts and test propositions or theories in the empirical realm (Ihalauw, 2008). On the other hand, qualitative research intends to understand the experience of the research subjects, such as behavior, perception, motivation, action, etc. holistically and by means of description in the form of words and language in a special natural context and by utilizing various natural methods (Kirk et.al in Jailani, 2013).

According to Creswell (2015), there are five approaches in qualitative research, namely: (1) narrative research, (2) phenomenological research, (3) grounded theory research, (4) ethnographic research, and (5) case study research. This research employed the case study method. Case study is one of the research methods which focuses on contemporary phenomena in several real-life contexts with the "how" and "why" questioning strategies

Figure 3. Kampung Development (Source: Author's Analysis, 2018)

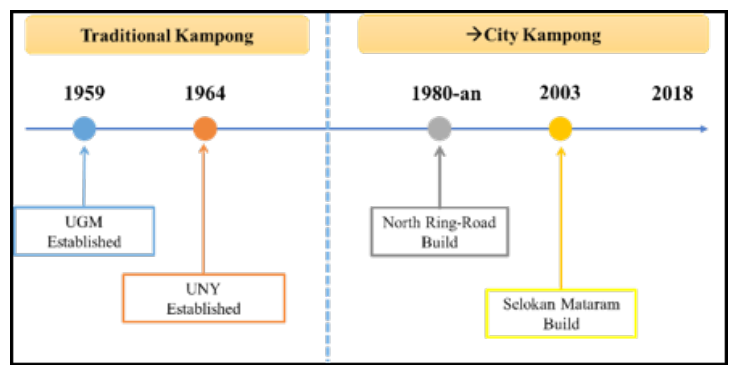


Figure 4. Map of Sample Location (Source: Survey, 2018)

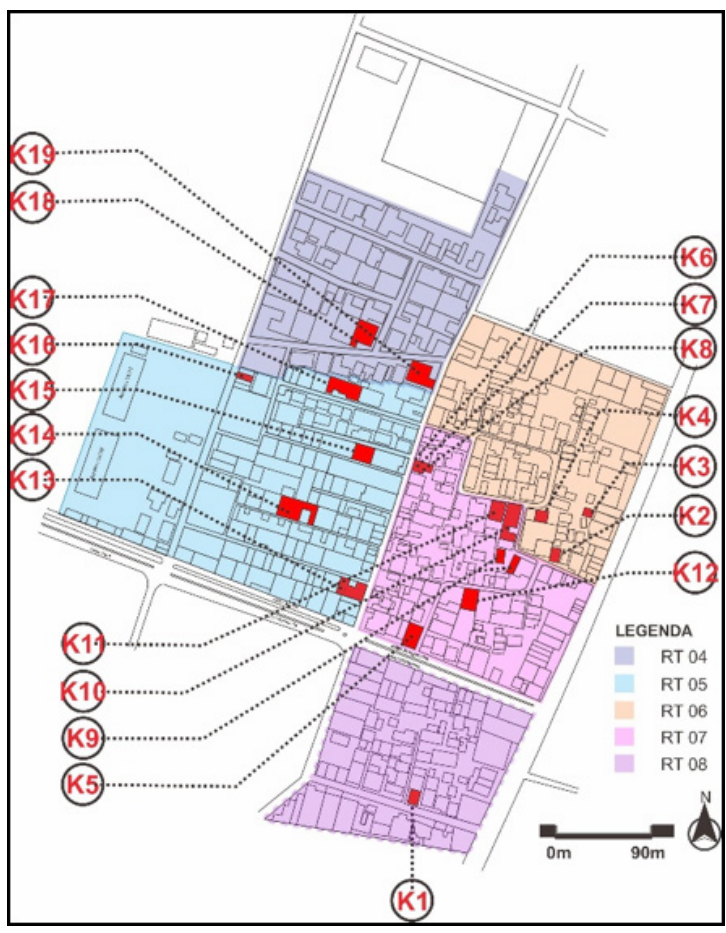

(Yin, 2003). The "how" questions were used to answer the research objectives of spatial transformation in HBE and "why" was aimed at finding out the cause. To find out the type of transformation, the cases in this study were identified in a radical (description integration) method, namely the successive comparison method in the course of time or the history of the development of a place (Koentjaraningrat, 1990). Each house was analyzed based on the transformation process every time a change in space occurred from the initial construction of the house to the present time; thus, the kind of transformation at the time of the transformation process in each case could be identified.

The research area was the area of RT 5 to RT 8 at Kampung Karangasem, Depok, Sleman. The number of research sample (19 cases) was determined by purposive sampling.

To obtain the research objectives, certain criteria were needed in the selection of research samples. The research sample criteria were as follows:

1. A home-based enterprise, namely a house with a dual function of both residential unit and place for business activities (Buildings that solely serve as either business place or residence were not included in the sample criteria.)
2. Houses with dominant economic activities in Kampung Karangasem

3. Houses with several orientations (facing the main road, village road, and alley)

4. Houses with horizontal development

The unit of analysis in this study was the space in HBE. The data were collected through observation and interview methods. Observations were carried out directly by the authors, while in-depth interviews were conducted to address all research variables.

\section{Process of Horizontal Spatial Transformation}

After conducting yearly analysis on the process of transformation in 19 research cases individually, the study finds different forms of adaptation strategies in each stage of house transformation. The houses that undergo horizontal spatial transformation are $\mathrm{K} 1, \mathrm{~K} 2$, K3, K4, K5, K7, K8, K9, K10, K11, K13, K17 and $\mathrm{K} 18$.

Meanwhile, others experience vertical transformation. The process of horizontal spatial transformation in each of these cases can be seen in the table 1 .

From the table above, it can be seen that the transformation of houses can take place in one or several stages with different types of transformation. There are 2 houses with three transformations, 4 houses with 2 transformations, and houses with 1 transformation. The space transformation was caused by the addition of business space (12 samples), the addition of residential space due to the urgency of a business space (1 sample), and the addition of residential space (1 sample). During the 1990s and early 2000s, all samples had become HBE.

The types of business that are most in demand in HBE are successively student boarding house (7 samples), food stalls ( 3 samples), laundry (6 samples), grocery stalls (2 samples). daily needs. 
Table 1. Process of Spatial Transformation

\begin{tabular}{|c|c|c|}
\hline Case & Start & Step 1 \\
\hline $\mathrm{K} 1$ & House/1980 & EoS/Food stall /1995 \\
\hline K2 & Rent House/1990 & EoS/Grocery stall/1991 \\
\hline K3 & House/1990 & SoS/Tofu distributor/1993 \\
\hline K4 & $\begin{array}{l}\text { Ru- } \\
\text { mah/1991 }\end{array}$ & $\begin{array}{l}\text { SoS/Food-Laundry ser- } \\
\text { vice- Bicycle Repair Work- } \\
\text { shop/2001-2005 }\end{array}$ \\
\hline K5 & $\begin{array}{l}\text { Boarding } \\
\text { house/1985 }\end{array}$ & $\begin{array}{l}\text { EoS/Rented space (counter, } \\
\text { ticketing, clothing shop/2001 }\end{array}$ \\
\hline K7 & House/1980 & SFoS/Food stall/1996-2005 \\
\hline K8 & House/1980 & EoS/Food stall, 2018 \\
\hline K9 & House/1980 & SoS/Boarding house/1990's \\
\hline K10 & House/1980 & EoS/Boarding house/1996 \\
\hline K11 & $\begin{array}{l}\text { House+Grocery } \\
\text { Stall/1980 }\end{array}$ & $\begin{array}{l}\text { SqoS/Boarding } \\
\text { house/2006-2010 }\end{array}$ \\
\hline K13 & $\begin{array}{l}\text { House+Boarding } \\
\text { house/1996 }\end{array}$ & $\begin{array}{l}\text { EoS, Rented space (laundry } \\
\text { service, tailor service, barber- } \\
\text { shop, drink stall)/ 2001-2005 }\end{array}$ \\
\hline K17 & House/1986 & EoS/Bedroom/2006-2010 \\
\hline K18 & $\begin{array}{l}\text { House+Boarding } \\
\text { house/1980 }\end{array}$ & EoS/Laundry service/2014 \\
\hline
\end{tabular}

\section{Type of Horizontal Spatial Transformation}

From the transformation process that has been analyzed above, several types of horizontal spatial transformation are found as follows.

\section{Extending of Space}

Horizontal extending of space is an adaptation strategy undertaken by households in terms of expansion, or an adaptation strategy done by expanding space. The expansion of space can be done by building new spaces on an unoccupied piece of land. The added space can be used as a residence or a place of business. The size of the space varies according to the space requirements of each homeowner.

In the case of $\mathrm{K} 1$, it can be seen that the transformation process takes place more than once. Homeowners seized business opportunities by setting up food stalls in 1985 after Kampung Karangasem began to be crowded due to the construction of UGM (Gadjah Mada University) and UNY (Yogyakarta State University) campuses near
EoS/Boarding house-Laun-

dry service/2000

EoS/ Tofu distributor $/ 1993$

EoS/Sewing course/

SfoS/Laundry ser-

vice/2001-2005

EoS, Bedroom, 2006-2010

EoS/Bathroom/2006's

EoS/Boarding house-tailor shop-rented parking lot/2011's

EoS/Boarding, food stall, laundry service/2000

the neighborhood. In the above case, the transformation with the extending of space strategy is carried out by the homeowner by gradually adjusting the availability of capital. The remaining vacant land in the area behind the house also motivated the homeowner to establish a second business in 2000 by making a boarding house business for female students.

In case $\mathrm{K} 2$, the transformation process took place once. In 1990, a house was built based on a friend's request to make a family-size rented house, which was rare at that time. In 1991, homeowners seized the opportunity of the proximity of the village to college campuses by building boarding houses in Kampung Karangasem as there was a great demand for facilities that fulfil the students' daily needs.

Homeowners then added a space in the front area of the house for expansion of housing and opened a grocery shop on the ground that this type of business was a business that could be run simultaneously with household activities without requiring special expertise. 
Horizontal Spatial Transformation of Home-Based Enterprises in Kampung Karangasem, Depok, Sleman Luluk Rani Puspita, Dwita Hadi Rahm
Figure 5. Extending of Space by Adding a Building in the Empty Land in the Front and Rear Areas of the House (Source: Author's Analysis, 2018)

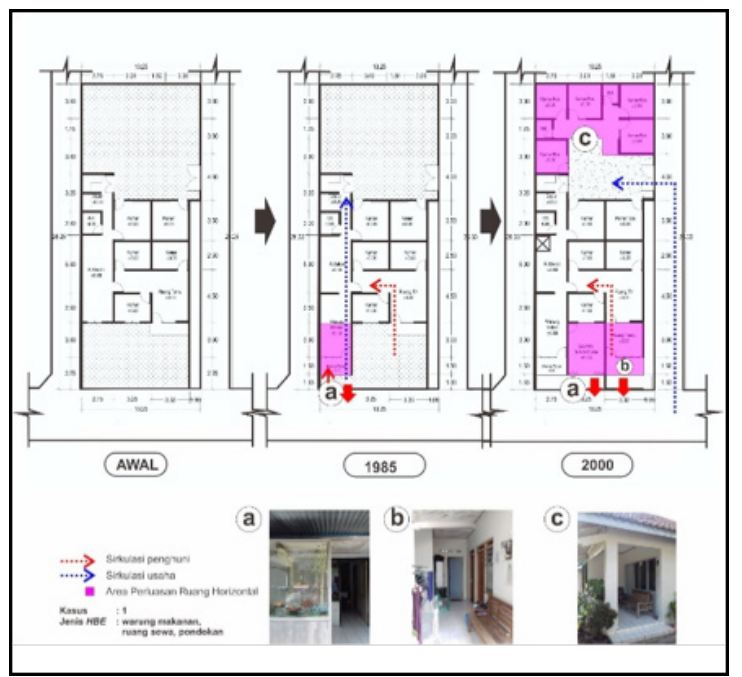

Figure 6. Extending of Space by Adding a Building in the Remaining Vacant Land and the Front Areas (Source: Author's Analysis, 2018)

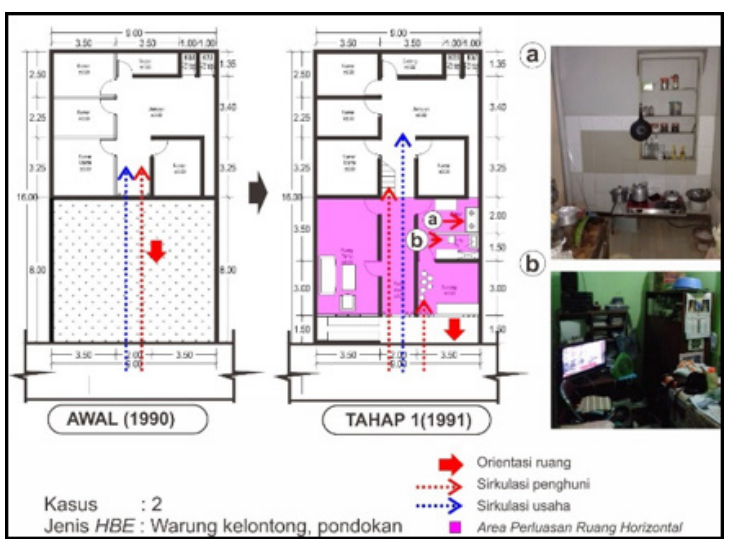

Figure 7. Extending of Space by Adding a Building in the Empty Land at the Side of House (Source: Author's Analysis, 2018)

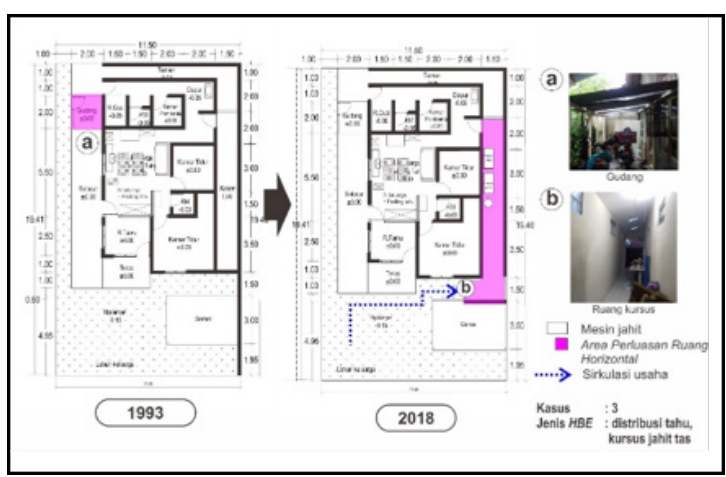

Figure 8. Extending of Space by Adding a Building in the Empty Land in Front of the House (Source: Author's Analysis, 2018)

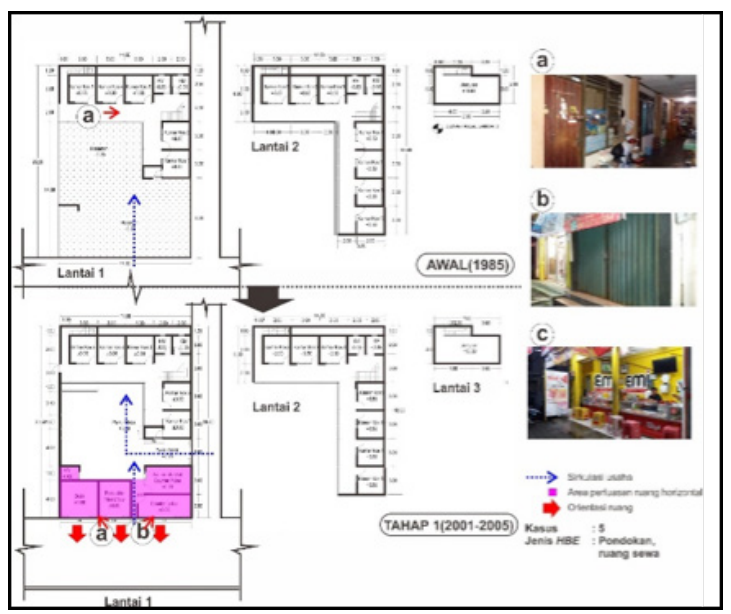

Figure 9. Extending of Space by Borrowing a Family Member's Room (Source: Author's Analysis, 2018)

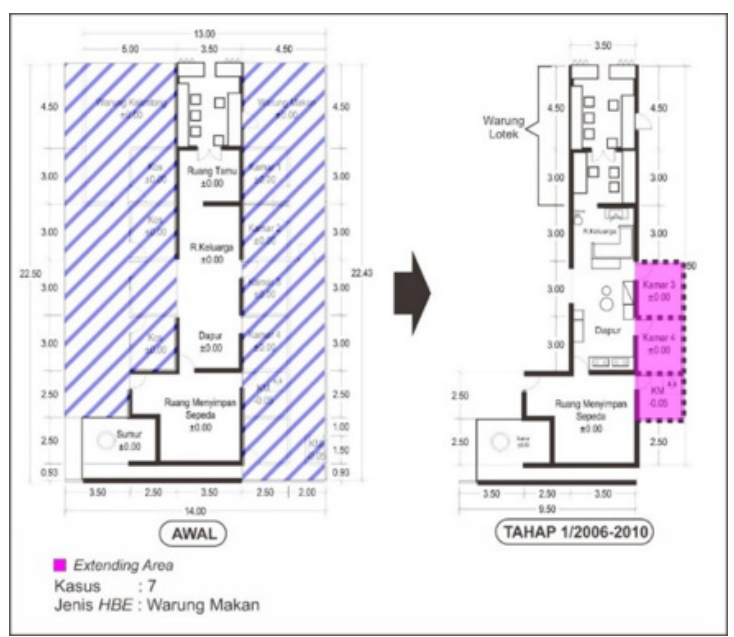

Figure 10. Extending of Space by Borrowing the Neighbor's Property

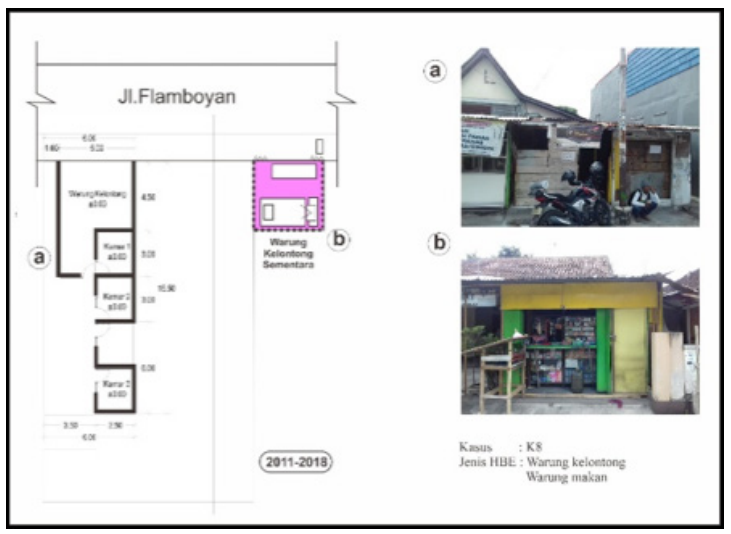


Figure 11. Extending of Space in the Front, Side, and Rear Areas of the House (Source: Author's Analysis, 2018)

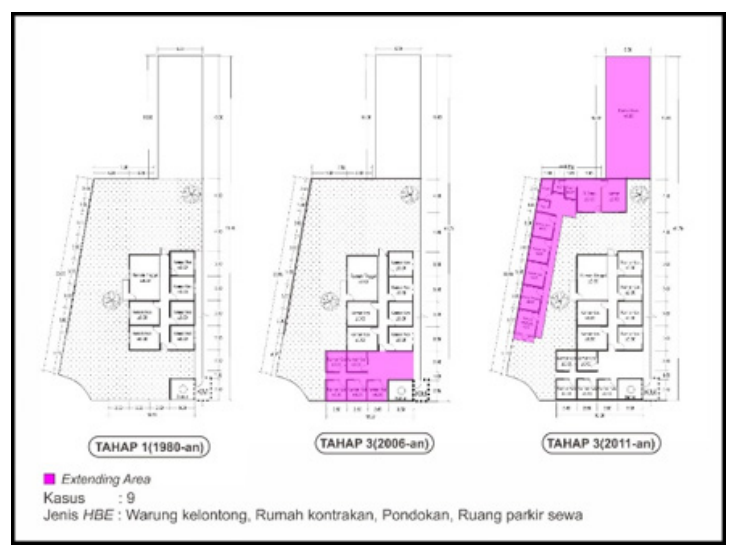

Figure 12. Extending of Space by Adding a New Building in the Empty Land

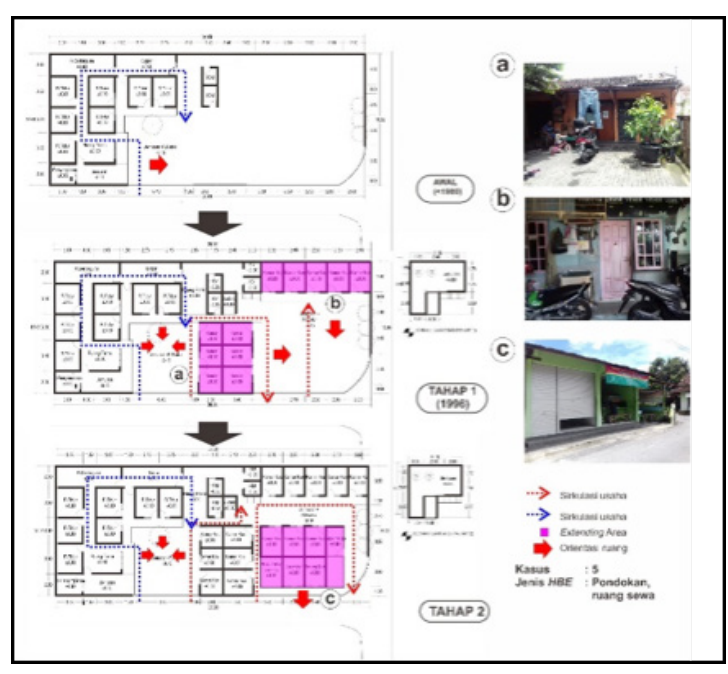

Figure 13. Extending of Space by Building a Boarding House in Front of the House (Source: Author's Analysis, 2018)

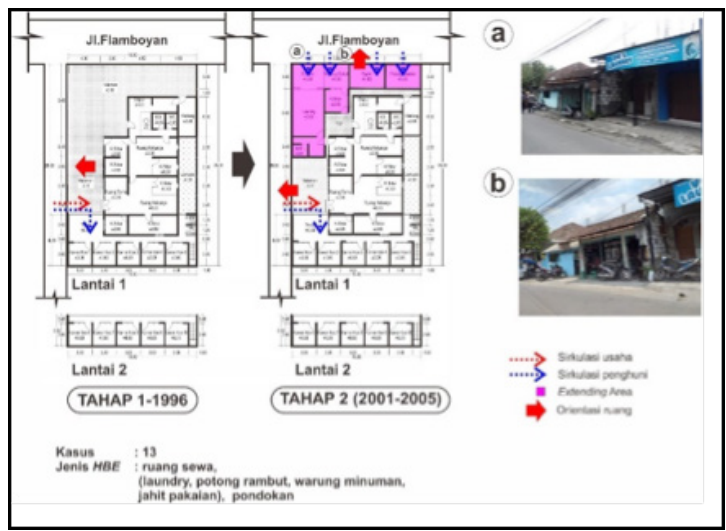

Homeowners created a TV-viewing room with plywood insulation alongside the stall as entertainment while working at the stall. In order to ensure that both household and business activities could run simultaneously, homeowners had moved the kitchen space to the area next to the TV watching room with plywood wall insulation. From this case, it can be seen that the horizontal spatial expansion was carried out to its full potential so that it occupied the entire area of the vacant land. The area of the house increased from only 55 $\mathrm{m} 2$ to $120 \mathrm{~m} 2$. The stall room was placed in the front area facing the road to facilitate access to customers.

In case $\mathrm{K} 3$, the house expansion took place twice. The first step was to make a warehouse space for the tofu packing business activities. In 2018, the house would be expanded again for a bag-making course business space in what formerly was the fish pond area.

In case $\mathrm{K} 5$, the homeowner inherited the boarding house business. The accommodation was a place for female students, mostly from UGM and UNY. Since the front area was still vacant, an expansion was then carried out in the front area of the house to build a business space for lease. This type of business space was in great demand due to the strategic location of the house directly facing the UNY Campus.

In case $\mathrm{K} 7$, the extending of space was done by borrowing a family member's room (the sister) because the homeowner did not have enough fund to renovate the house. The house was inherited from the homeowner's parents and divided among the siblings based on the size of the space. The limited space did not allow for a bedroom, while the existing space was mainly used to support business activities in the form of lotek (traditional Javanese dish) food stall as the homeowner's main source of income. Lotek buyers were local residents and students living in Kampung Karangasem. The older brother of the homeowner then lent his bedroom as his younger brother had not been able to build his own room. In this case, the homeowner was able to borrow the space without paying rent due to kinship or familial relationship. From this case, it can be seen that the expansion of space can also occur in private space. 
Figure 14. Extending of Space by Adding a Building in the Empty Land next to the House (Source: Author's Analysis, 2018)

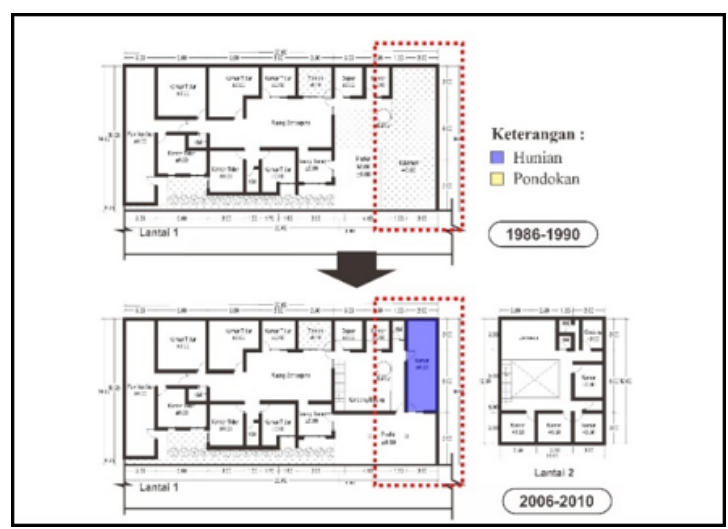

Figure 15. Extending of Space by Adding a Room Behind the House (Source: Author's Analysis, 2018)

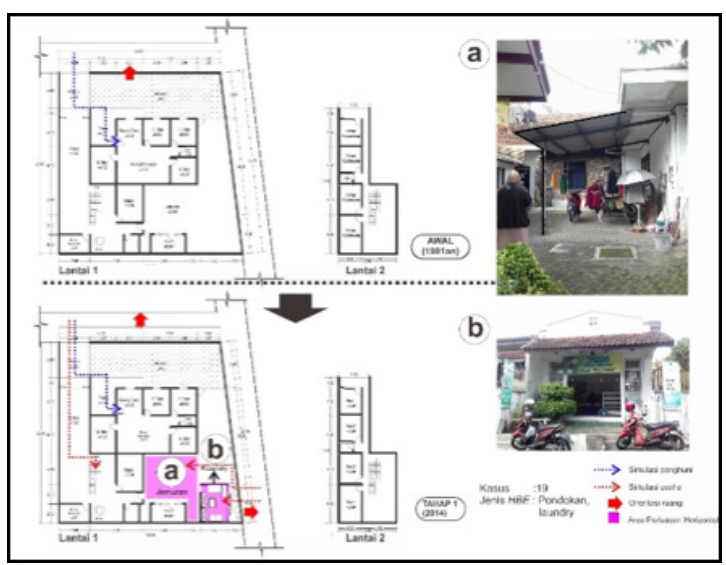

The next case is case $\mathrm{K} 8$ in which the homeowner's space was extended by borrowing the neighbor's land to set up a temporary grocery shop while the house was being built. This is an effort of the homeowner to maintain his business. In turn, a rental cost must be paid with an amount that has been agreed by both parties.

In $\mathrm{K} 9$, the extending of space was done in stages to adjust capital availability. At first the homeowner built a boarding house in the front area of the house, and then again in the side and rear areas of the house to expand the boarding house, rented house, as well as making a space for the tailor worskhop and rental parking spaces.

In $\mathrm{K} 10$, the expansion was carried out by homeowners to build a boarding house business in their workplace. The accommodation offered a promising prospect due to the proximity of the village to UGM and UNY.
In case K13, space expansion was carried out in the area of the front of the house to make a business space for lease. The type of business varies depending on the contractor. The businesses occupying the space were a laundry service, a tailor service, and a barbershop. The construction of this business space was based on the great demand of rented space due to the strategic location of the area that was crowded with students. In addition, the construction of the Mataram canal also caused some displaced traders to find new business spaces.

In case $\mathrm{K} 17$, expansion was done on the vacant lot at the right side of the house in the form of a new room with a bathroom that the homeowner's brother would occupy. There was no available space inside the house for an additional resident, thus, a new room was built from scratch.

In case K18, expansion was done to set up a laundry business. This business was established after the homeowner resigned from his old job and seized the opportunity of the village which was full by students who needed such service.

From some of the cases above, it appears that the transformation can take place one or several times to adjust business space requirements and capital availability. Expansion of space can occur in business and private spaces as well as on owned or borrowed land that belongs to relatives and neighbors. The expansion of space to the relative's property is based on close kinship, which means that there is no need to pay rent. On the contrary, when expansion is done to the neighbor's property, despite a good relationship, the homeowner still must pay rent.

\section{Sharing of Space}

Sharing of Space is the maximum use of space, typically for accommodating both household and home business activities. The type of space that can be used for sharing varies from the service room (KM, kitchen, and warehouse), semi-public space (family room and living room), or public space (terrace and yard). Spatial distribution areas can also be adjusted with business needs. Some use only certain parts of the room, but others may use nearly the entire space as a business space. 
Figure 16. Sharing of Space in Family Room (Source: Author's Analysis, 2018)

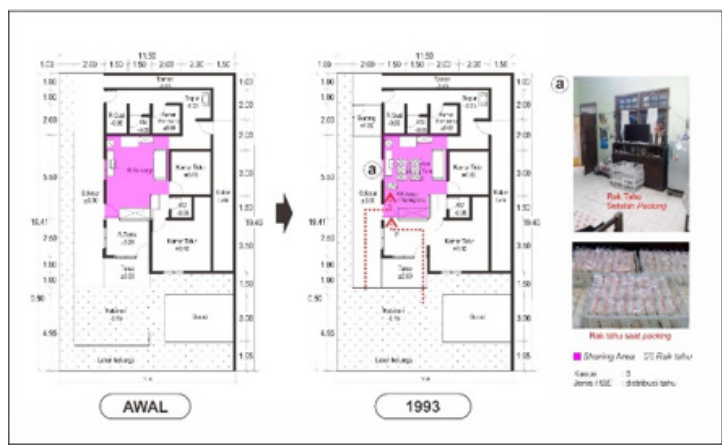

Figure 17. Sharing of Space in the Guest Room, Kitchen, and Service Room (Source: Author's Analysis, 2018)

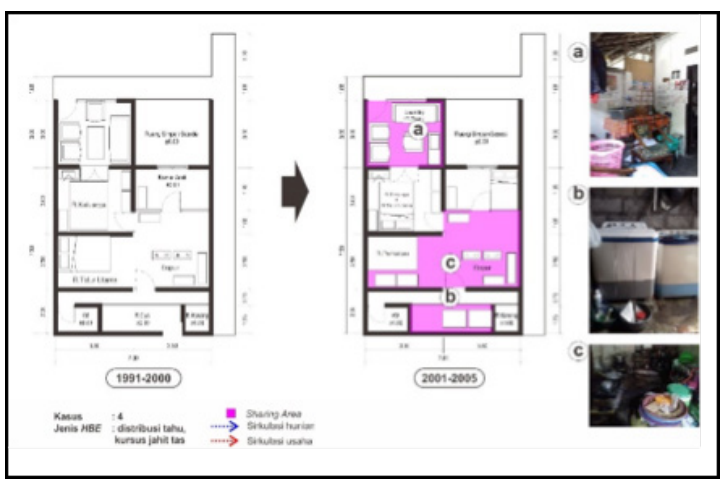

Figure 18. Sharing of Bathroom (Source : Author's Analysis, 2018)

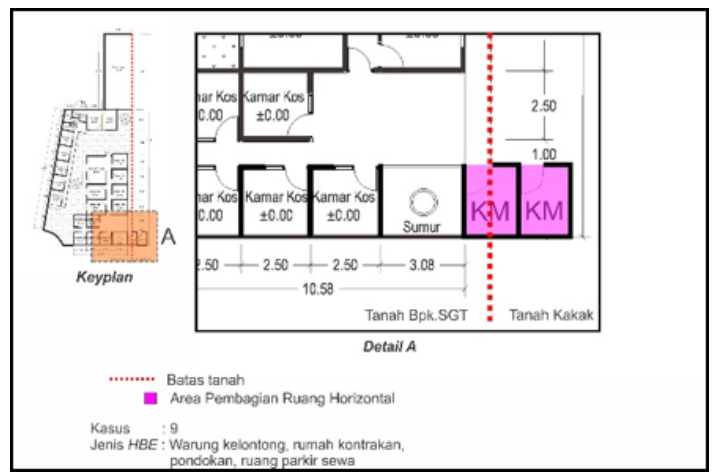

In case K3, the homeowner had a tofu packaging and distribution business. When the tofu packing activity took place, plastic shelves were not stacked, but placed one by one in lined-up order due to the fragility of tofu. This arrangement model fit the space of the living room area. When the packing process had finished, the empty shelves were then stacked and placed at the side of the living room, so that the living room returned to its previous arrangement. This process did not interfere with the function of the family room because it only took place at certain hours.

In case $\mathrm{K} 4$, business activities were the main source of revenue for the homeowner. In one house, there were 3 business activities namely a workshop, a food manufacturing business, and a laundry service. The small size of the house $(73 \mathrm{~m} 2)$ and the small size of the land only leave a small amount of vacant land that made it impossible to build another space. The problem was resolved by conducting the business and household activities in the same area. The first room transformed for business activities was the living room, which also functioned as a laundry business space. This business provided hand-washing and machine-washing services. In the small living room (3×3.5), a table was added for weighing the customers' clothes and ironing. The second shared room is the laundry room in the back of the house. The washing room was placed in the back area, separated from the laundry reception room, because the living room area was no longer able to accommodate the size of the washing machines. In the laundry room, household and laundry activities went together. The third shared room is the kitchen. This space was used for daily cooking as well as a place to make food to order.

In case $\mathrm{K} 9$, the homeowner owned a boarding house business. The house was inherited from the parents and divided among the siblings based on the space area. At first the owner of the house could not build a bathroom of his own, so the bathroom, which was located in his brother's inherited land, was then used together both for personal use and for the room renters. This use is allowed without paying additional cost because of kinship relation.

From some of the cases above, it can be seen that the division of space is carried out for several reasons including spatial effectiveness, the lack of available vacant land for spatial development, and the lack of capital for new spatial development.

\section{Shifting of Space}

The eagerness to take business opportunities is often not supported by land and space availability. There is a limitation for houses with a small land area to expand the space. This underlies the need for adaptation strategies 
Figure 19. Shifting of Space in the Main Bedroom (Source: Author's Analysis, 2018)

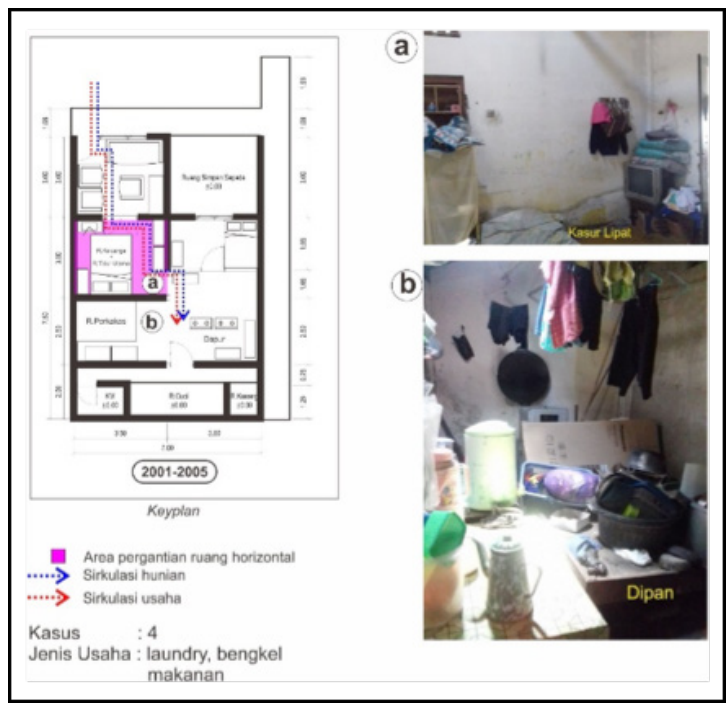

Figure 20. Shifting of Space in the Food Stall Area

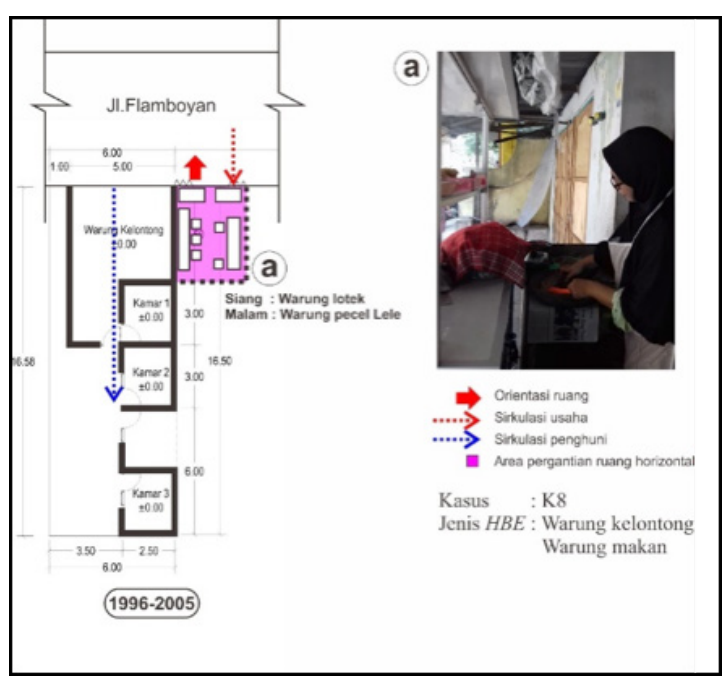

in the transformation process such as room changes to accommodate business and domestic activities at different times of the day.

In case $\mathrm{K} 4$, after having divided the space once, the space was still not sufficient for business space. For this reason, the main bedroom was reserved by the owner to be used as a storage room for cooking utensils and the laundry business's drying area. As a result, the room had a dual function with time separation. During the day, the room was used for watching $T V$, while at night it was used as the main bedroom for the homeowner.

To facilitate the transition of space functions, not much furniture was placed in the family room. Only a carpet with a TV table was placed in the room. At night, the owner of the house would lay out a mattress to repose.

In case $\mathrm{K} 7$, the owner of the $\mathrm{K} 7$ was the older brother of the K8 owner. The owner of the K7 borrowed the K8 room at night to sell pecel lele, a traditional fried catfish dish served with rice and sambal. During the day, this space was used by the K8 owner to sell lotek. This change of space was based on kinship relation.

From some of the cases above, it appears that Shifting of Space is an attempt to use space where there is no other available space that can be used for business. Shifting space can be done on one's own land or a close neighbor's property, particularly those who still count as relatives.

\section{Squishing of Space}

In the process of studying several research samples, the current study found another adaptation strategy in addition to spatial expansion, i.e. Squishing of Space. Squishing of Space is an adaptation strategy that is done by compressing the room size so that it is smaller than before. Compression can occur in either business or residential space. In the research samples, Squishing of Space were caused by several things including changes in household size and the need for new business space. The choice to shrink a particular space can also be influenced by the orientation of the business space which requires the placement of space in a location facing the road.

In $\mathrm{K} 9$, the homeowner initially lived in a house that he inherited from his parents. In 2006, the residential space was compressed to be used as student lodgings. As a source of income, the K9 owner changed their residential spaces to become lodgings. The area of the house narrowed from what was $94 \mathrm{~m} 2$ to $23 \mathrm{~m} 2$.

In case $\mathrm{K} 10$, it appears that the area inside the red box was the area of the student housing which was depreciated to be used as a residence. The area of the shelter space was reduced from $182 \mathrm{~m} 2$ to $124 \mathrm{~m} 2$. This compression of space occurs due to a change in household size. The children of the homeowner, along with their spouses, lived in one of the rented rooms as they could not afford their own place yet. 
Figure 21. Squishing of Space in the Dwelling Area (Source: Author's Analysis, 2018)

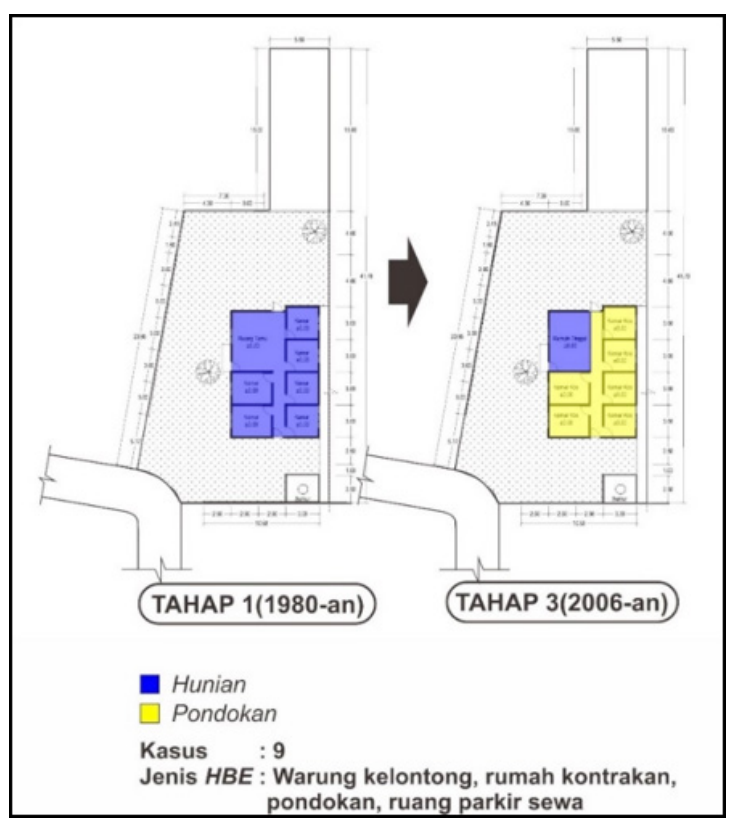

Figure 22. Squishing of Space in the Boarding House Area (Source : Author's Analysis, 2018)

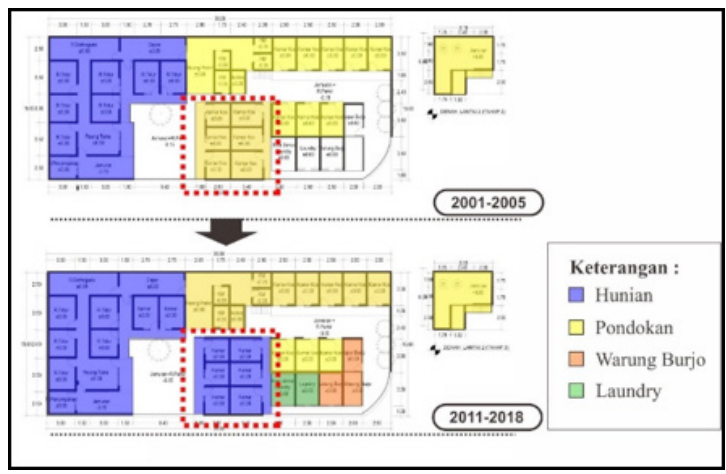

In case $\mathrm{K} 11$, the residential space was narrowed to allow the expansion of the boarding house. The area of the residential space, which was $195 \mathrm{~m} 2$, was reduced to $163 \mathrm{~m} 2$ by transforming the former children's bedrooms and the back area of the house into additional rooms for rent. This decision was taken to make use of the children's bedrooms which were vacant as the former inhabitants left to settle down and have their own homes.

In case K12 above, the homeowner established a telephone shop business in 2002 using the garage space. The garage had an area of 46.5 $\mathrm{m} 2$ divided into two rooms: one for tenant and
Figure 23. Squishing of Space in the Dwelling Area (Source : Author's Analysis, 2018)

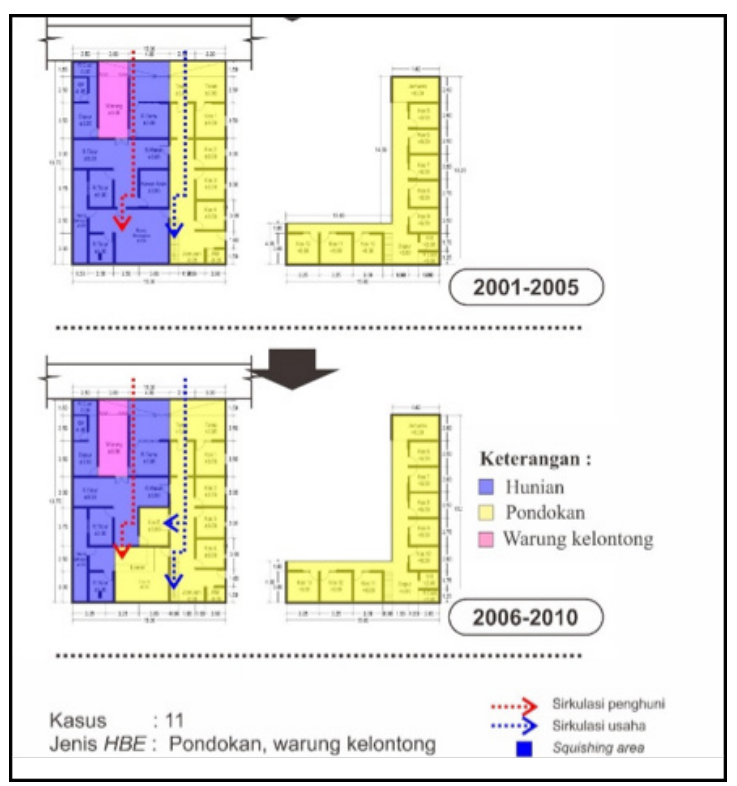

Figure 24. Squishing of the Garage Space (Source: Author's Analysis, 2018)

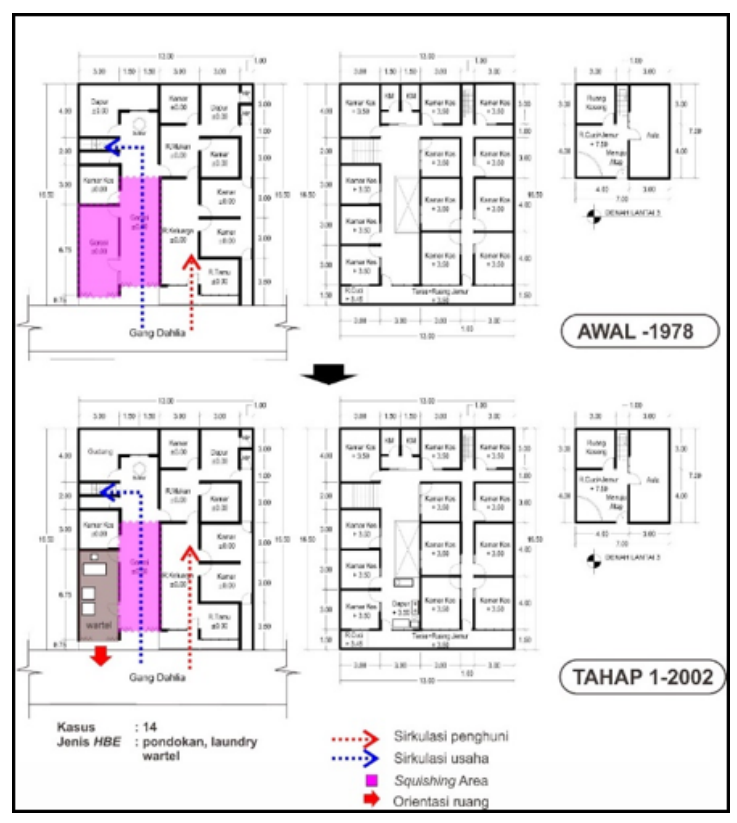

one for the homeowner. The garage area was then reduced to $25.5 \mathrm{~m} 2$. The garage was an ideal space for a telephone shop because the business required a space that directly faced the road. The size of the garage allowed the room to function as a business space and contain furniture such as a box and a cashier desk.

From some of the cases above, it is found that the expansion of business space has led to 
Horizontal Spatial Transformation of Home-Based Enterprises in Kampung Karangasem, Depok, Sleman Luluk Rani Puspita, Dwita Hadi Rahmi the squishing of private space. Conversely, the expansion of private space can also cause the squishing of business space due to changes in household size and the addition of business space. Ultimately, when neither the sharing nor the shifting of space is possible to do, the squishing of space becomes an option for when there is no vacant land.

\section{Horizontal Spatial Transfor mation in HBE in Kampung Karangasem}

The houses in Kampung Karangasem are experiencing developments over time. In the span of the period $<1980-2018$, each house had undergone a different transformation process. The process of housing transformation into HBE in Kampung Karangasem takes place in one or several stages depending on the availability of funds and space requirements. At first only a few houses were made into a business space, but over time almost all of the houses have changed into HBE. The most dominant type of business is a business that accommodates the needs of students both in terms of residence and daily necessities.

According to Yahya et.al in Avogo et.al. (2017) transformation of homes can be done vertically and horizontally. Although this is consistent with the findings, it must be noted that horizontal transformation is more commonly found than vertical transformation. The process of transforming a residential house into $\mathrm{HBE}$ affects the spatial changes of the house. This is in accordance with what was stated by Baper et.al (2010) where changes in spatial patterns in and adaptation to culture are one indicator of the transformation process.

Based on the findings, the transformation of residential houses into $\mathrm{HBE}$ is done by homeowners by making spatial changes in the area inside and outside the house. This confirms the theory of Tipple (1991); Huba \& Yohannes, (2015) that transformation in residential houses refers to "alteration" or "extension." The findings also add to what Tipple has stated on how the "extension" of spatial expansion does not only occur in the area of the house but can also extend to neighboring area or the relatives properties around the house. The extensions to relatives' lands are based on kinship relation, hence there is no need to pay rent, while the expansion into the neighboring land, in spite of good relationship, will still be charged with rental costs.

In regard to the previously discussed four adaptation strategies on horizontal transformation, this study has managed to develop Marsoyo's (2002) theory on the household adaptation strategy to "build spatial capital" for HBE which consists of three categories, namely (a) Sharing of Space (division of space) (b) Extending of Space (space), and (c) Shifting of Space (space change). This research finds an additional intensive adaptation strategy (development of areas in the house), namely the Squishing of Space.

In Kampung Karangasem, the Extending of Space strategy is the most popular strategy as based on the majority of the research sample, there is still available vacant land either in the front, side or back of the house. The Sharing of Space strategy becomes the choice when homeowners aim to achieve space efficiency or are constrained by limited capital availability. Meanwhile, the Shifting of Space (change of space) is an option for when the area of the house does not have sufficient land or space. The new strategy found is Squishing of Space, in which the expansion of business space leads to the compression of private space and vice versa due to changes in household size and an addition of business space.

\section{Conclusion and Recommendations}

The houses in Kampung Karangasem experience a transformation from residential houses to HBE to accommodate the needs of students in the nearby college campuses by providing shelter and daily needs. The transformation process takes place in one or several stages to adjust the needs and capital availability.

This study finds that the horizontal spatial transformations include the Extending of Space, the Sharing of Space, the Shifting of Space, and the Squishing of Space, which adds to the results of Marsoyo's (2012) research.

After completing this research, the writer sees a symptom of very rapid development in this village, i.e. from a residential area to a business area. The change from housing to HBE has had both positive and negative effects. The 
positive impact is the increase in the welfare of the homeowners, while the negative impact is a spatial change that is neither directed nor controlled. From the micro side, this can eliminate the essence of the function of the house as a residence. Additionally, the need for private space will be increasingly ignored. Within the scope of the area, this phenomenon can gradually eliminate the characteristics of Kampung as the distinctive identity of Yogyakarta. For this reason, there is a need for guidelines regarding spatial planning and areas in villages with $\mathrm{HBE}$.

\section{Reference}

Avogo, F. A., Wedam, E. A., \& Opoku, S. M. (2017). Housing transformation and livelihood outcomes in Accra, Ghana. Cities, 68(November 2016), 92-103. https://doi.org/10.1016/j.cities.2017.05.009

Baper, S. Y., Hassan, A. S., Mustafa, F. A., \& Ismail, S. (2010). A Theoretical Study on Modernity and Transformation in Architecture.14 th International Planning History Society Conference (July).

Creswell, J. W. (2007). Qualitative inquiry and research design: Choosing among five approaches (2nd ed.). Thousand Oaks, CA: Sage Publications

Gough, K. V. and P. W. Kellett (2001). "Housing Consolidation and Home- based Income Generation: Evidence from self-help settlements in two Colombian cities." Cities 18(4): 235-47.

Habraken, N. J. (1983). Transformations of the Site. Cambridge: Awater Press. Retrieved from https://books.google.co.id/ books?id=XJp1HAAACAAJ

Hartiningsih. (2008). Perubahan sistem spasial rumah tinggal berfungsi ganda di daerah umbulharjo yogyakarta (Vol. 2).

Huba, N., \& Yohannes, K. (2015). Space Use and Environmental Effects of HomeBased Enterprises. The Case of Buguruni Mnyamani Informal Settlement, Dar Es Salaam , Tanzania, 5(4), 118-119.

Ihalauw. (2008). Konstruksi Teori. Jakarta : Grasindo.

Jailani, M. S. (2013). Ragam Penelitian Qualitative (Ethnografi, Fenomenologi, Grounded Theory,dan Studi Kasus, Vol 4, $p: 41-50$

Jr, Marti (1981). Space Operational Analysis. West Lafayette, Indiana: PDA Publisher.
Kamus Besar Bahasa Indonesia. [Online]. Diakses 11 januari 2017. Tersedia di kbbi. kemdikbud.go.id

K.Yin, R. (2003). Case Study Research Design and Methods. In L. Bickman \& Debra J.Rog (Eds.) (Third Edit, pp. 1-116). California, America: Sage. https://doi.org/10.1097/ $\mathrm{FCH} .0 \mathrm{b013e31822dda9e}$

Koentjaraningrat. (1990). Manusia dan kebudayaan di Indonesia. Penerbit Djambatan. Retrieved from https://books. google.co.id/books?id=_LHGAAAACAAJ

Marsoyo, A. (2012). Constructing Spatial Capital Household Adaptation Strategies in Home-Based Enterprises in Yogyakarta. University of Newcastle upon Tyne.

Purwanto Setyo Nugroho, Haryana, S. S. (2003). Studi Perubahan Spasial Rumah Tinggal Menjadi Rumah Pondokan Mahasiswa Di Yogyakarta. Teknosains, 16B, 111-127.

Strassmann, W. P. (1986). "Types of Neighbourhood and Home-Based Enterprises: Evidence from Lima, Peru." Urban Studies 23: 485-500.

Strassmann, W. P. (1987). "Home-based Enterprises in Cities of Developing Countries." Economic Development and Cultural Change 36(1): 121-44.

Sumarjo. (1999). Kajian perubahan bentuk arsitektur rumah pondokan mahasiswa di daerah pinggiran kota. Gadjah Mada University.

Tipple, A. G. (1991). Self Help Transformations of Low Cost Housing: An Introductory Study: Prepared for the Overseas Development Administration (ODA). London: Urban International Press for the Overseas Development Administration (ODA). Retrieved from https://books. google.co.id/books?id=iB5PAAAAMAAJ

Tipple, G. (2005). The place of homebased enterprises in the informal sector: Evidence from Cochabamba, New Delhi, Surabaya and Pretoria. Urban Studies, 42(4), 611-632. https://doi. org/10.1080/00420980500060178 